Portland State University

PDXScholar

$1-6-2021$

\title{
Assisted Living Communities that Accept Medicaid are Not Subject to Federal Oversight
}

\author{
Lindsey Smith \\ Portland State University \\ Sarah Dys \\ Portland State University \\ Paula Carder \\ Portland State University, carderp@pdx.edu
}

Follow this and additional works at: https://pdxscholar.library.pdx.edu/aging_pub

Part of the Gerontology Commons

Let us know how access to this document benefits you.

\section{Citation Details}

Smith, L., Dys, S., \& Carder, P. (2021). Assisted Living Communities that Accept Medicaid are Not Subject to Federal Oversight. Journal of Gerontological Social Work, 1-4. https://doi.org/10.1080/ 01634372.2020 .1865497

This Post-Print is brought to you for free and open access. It has been accepted for inclusion in Institute on Aging Publications by an authorized administrator of PDXScholar. Please contact us if we can make this document more accessible: pdxscholar@pdx.edu. 


\title{
Assisted Living Communities that Accept Medicaid are Not Subject to Federal Oversight
}

\author{
Lindsey Smith , Sarah Dys \& Paula Carder
}

To cite this article: Lindsey Smith , Sarah Dys \& Paula Carder (2021): Assisted Living Communities that Accept Medicaid are Not Subject to Federal Oversight, Journal of Gerontological Social Work, DOI: 10.1080/01634372.2020.1865497

To link to this article: https://doi.org/10.1080/01634372.2020.1865497

曲 Published online: 06 Jan 2021.

Submit your article to this journal $\widetilde{x}$

Q View related articles ¿

View Crossmark data $[\pi$ 


\section{Assisted Living Communities that Accept Medicaid are Not Subject to Federal Oversight}

\section{Dear Editor,}

We commend Mauldin et al. (2020) for their recent article titled "Supports and gaps in federal policy for addressing racial and ethnic disparities among long-term care facility residents," which addresses opportunities to mitigate racial and ethnic disparities in long-term care (LTC) through federal policies. However, we would like to clarify a statement regarding federal oversight of assisted living (AL) communities made by the authors.

Mauldin et al. describe the Centers for Medicare \& Medicaid Services (CMS) and Long-term Care Ombudsman regulations as providing federal oversight relevant to addressing racial and ethnic disparities in LTC. They write that half of AL communities are subject to federal oversight by virtue of their Medicaid certification. This is inaccurate. AL communities that accept Medicaid are indirectly subject to certain CMS rules (Government Accountability Office, 2019). However, AL communities receiving Medicaid are overseen by state agencies, without direct CMS surveillance. State agency monitoring lacks standardization in reporting, enforcement, and standards (Government Accountability Office, 2018). While the authors do acknowledge state variation in AL regulation, it is important to further clarify the limits of federal oversight for this LTC setting.

AL communities are not included in the definition of LTC used in the CMS federal code, so, the provisions in this section, cited by Mauldin et al., do not apply to them (Requirements for Long Term Care Facilities, 42 C.F.R. $\$ 483$, 2020). While CMS sets standards for nursing facility (NF) surveillance topics and survey frequency (Government Accountability Office, 2019), it has no parallel process for AL. If a NF surveyed receives Medicare, state compliance surveyors report results to a regional federal CMS office. This office certifies facilities to continue operating and providing reimbursable care to Medicare and Medicaid beneficiaries. If the facility is enrolled only in Medicaid, the state agency certifies compliance, determining whether the facility may continue providing Medicaid-funded care (Centers for Medicare \& Medicaid Services, 2020). CMS may cite states that certify facilities to receive Medicaid funds to noncompliant NF without appropriate corrective action (Government Accountability Office, 2019).

While almost half of AL community settings are authorized or certified to provide Medicaid services, this "certification" is not a federal certification. This 
statistic comes from the National Post-Acute and Long-term Care Study which describes the proportion of residential care communities that, when surveyed, report being certified or authorized to receive Medicaid payments. A facility may respond positively to this survey question even if the state they operate in does not have a specific Medicaid certification process (Harris-Kojetin et al., 2019). So, while it may appear that CMS provides oversight to half of AL communities, it is not reflected in practice.

An example of a federal rule that established requirements for HCBS, including AL, is the 2014 HCBS rule change (Centers for Medicare \& Medicaid Services (CMS), HHS, 2014). This rule established person-centered and non-institutional expectations for states to comply with, but did not change how CMS oversees states' monitoring and enforcement after waivers are funded (Government Accountability Office, 2018). Specifically, CMS requires state agencies to demonstrate that their policies meet applicable federal rules to receive federal approval of their HCBS waivers. However, even in this case, federal oversight of AL is minimal, as CMS does not oversee how or to what extent states enforce these rules or whether these rules have been upheld by $\mathrm{AL}$ communities receiving federal funds (Government Accountability Office, 2019).

We appreciate the authors' description of opportunities for federal policy intervention in LTC, especially the Long-Term Care Ombudsman program, which is often overlooked and does provide oversight to AL communities (Snyder \& Benson, 2017). We recognize the complexity and nuance in describing the policy landscape for various LTC settings, particularly in the context of racial and ethnic disparities. Though HCBS waivers have been instrumental in expanding Medicaid beyond NF, there is a larger gap in federal policy protecting AL resident rights in comparison to NFs worth considering (Thach \& Wiener, 2018). In particular, more research is needed to understand how federal policies might reduce racial and ethnic disparities in AL communities (Fabius \& Thomas, 2019).

Lindsey Smith M. P. P. School of Public Health, Oregon Health \& Science University-Portland State University, Portland, Oregon, USA Institute on Aging, College of Urban and Public Affairs, Portland State University, Portland, Oregon, USA @ linsmith@pdx.edu (1) http://orcid.org/0000-0003-4630-3114

Sarah Dys M. P. A. School of Public Health, Oregon Health \& Science University-Portland State University, Portland, Oregon, USA Institute on Aging, College of Urban and Public Affairs, Portland State 
University, Portland, Oregon, USA http://orcid.org/0000-0002-4310-3048

\author{
Paula Carder Ph.D. \\ School of Public Health, Oregon Health \& Science University-Portland \\ State University, Portland, Oregon, USA \\ Institute on Aging, College of Urban and Public Affairs, Portland State \\ University, Portland, Oregon, USA \\ D http://orcid.org/0000-0002-8584-5226
}

Received 25 November 2020; Revised 14 December 2020; Accepted 14 December 2020

\title{
Conflicts of interest
}

The authors have no conflicts of interest to disclose.

\section{References}

Centers for Medicare \& Medicaid Services. (2020). Nursing homes. CMS.Gov. Retrieved November 12, 2020, from https://www.cms.gov/Medicare/Provider-Enrollment-andCertification/CertificationandComplianc/NHs

Centers for Medicare \& Medicaid Services (CMS), HHS. (2014). Medicaid program; state plan home and community-based services, 5 -year period for waivers, provider payment reassignment, and home and community-based setting requirements for community first choice and home and community-based services (HCBS) waivers. Final rule. Federal Register, 79(11), 2947. https://www.govinfo.gov/content/pkg/FR-2014-01-16/pdf/2014-00487.pdf

Fabius, C. D., \& Thomas, K. S. (2019). Examining black-white disparities among medicare beneficiaries in assisted living settings in 2014. Journal of the American Medical Directors Association, 20(6), 703-709. https://doi.org/10.1016/j.jamda.2018.09.032

Government Accountability Office. (2018). Medicaid assisted living services: Improved federal oversight of beneficiary health and welfare is needed (Report to Congressional Requesters GAO-18-179). https://www.gao.gov/assets/690/689302.pdf

Government Accountability Office. (2019). Elder abuse: Federal requirements for oversight in nursing homes and assisted living facilities differ (GAO-19-599). https://www.gao.gov/assets/ 710/700985.pdf

Harris-Kojetin, L., Sengupta, M., Rome, V., Valverde, R., \& Caffrey, C. (2019). Long-term care providers and services users in the United States, 2015-2016 (No. 43; Vital and Health Statistics, Series 3). U.S. Department of Health and Human Services, Centers for Disease Control and Prevention, National Center for Health Statistics. https://lccn.loc.gov/ 2018056225

Mauldin, R. L., Lee, K., Tang, W., Herrera, S., \& Williams, A. (2020). Supports and gaps in federal policy for addressing racial and ethnic disparities among long-term care facility residents. Journal of Gerontological Social Work, 63(4), 354-370. https://doi.org/10.1080/ 01634372.2020 .1758270 
Requirements for Long Term Care Facilities, 42 C.F.R. $\$ 483$. (2020). https://www.ecfr.gov/cgibin/text-idx?SID=02eb890fcb4a862d50064cfb9d2810a6\&mc=true\&tpl=/ecfrbrowse/ Title42/42cfr483_main_02.tpl

Snyder, J., \& Benson, W. F. (2017). Adult protective services and the long-term care ombudsman program. In X. Dong (Ed.), Elder abuse (pp. 317-342). Springer International Publishing. https://doi.org/10.1007/978-3-319-47504-2_15

Thach, N. T., \& Wiener, J. M. (2018). An overview of long-term services and supports and Medicaid: Final report. RTI International. https://aspe.hhs.gov/basic-report/overview-longterm-services-and-supports-and-medicaid-final-report\#MedicaidRole 